\title{
Narrative reflective practice in medical education for residents: composing shifting identities
}

This article was published in the following Dove Press journal:

Advances in Medical Education and Practice

16 December 2010

Number of times this article has been viewed

\author{
Jean Clandinin' \\ Marie Thérèse Cave ${ }^{2}$ \\ Andrew Cave ${ }^{2}$ \\ 'Center for Research for Teacher \\ Education and Development, \\ University of Alberta, Edmonton, \\ Alberta, Canada; ${ }^{2}$ Department of \\ Family Medicine, Faculty of Medicine \\ and Dentistry, University of Alberta, \\ Edmonton, Alberta, Canada
}

\begin{abstract}
As researchers note, medical educators need to create situations to work with physicians in training to help them attend to the development of their professional identities. While there is a call for such changes to be included in medical education, educational approaches that facilitate attention to the development of medical students' professional identities, that is, who they are and who they are becoming as physicians, are still under development. One pedagogical strategy involves narrative reflective practice as a way to develop physician identity. Using this approach, medical residents first write narrative accounts of their experiences with patients in what are called "parallel charts". They then engage in a collaborative narrative inquiry within a sustained inquiry group of other residents and two researcher/facilitators (one physician, one narrative researcher). Preliminary studies of this approach are underway. Drawing on the experiences of one medical resident in one such inquiry group, we show how this pedagogical strategy enables attending to physician identity making.
\end{abstract}

Keywords: physician identity formation, residency

\section{A theoretical backdrop}

The development of physician identity is an important part of medical education. While there are various conceptualizations of professional identity, ${ }^{2}$ there is some agreement that professional identities are composed over a lifetime, ${ }^{3}$ are constituted in and on both personal and professional landscapes, ${ }^{4}$ are interwoven with personal identities, ${ }^{5}$ are fluid and changing over time, ${ }^{6}$ are multiple and sometimes conflicted, and are embodied. ${ }^{7}$ Conceptions of identity as narrative life compositions have been developed by psychologists, ${ }^{3,8}$ philosophers, ${ }^{9}$ and educational theorists. ${ }^{10}$

Teaching using narrative reflective practice approaches creates pedagogical situations where physicians in training learn to inquire into their emerging professional and personal identities. Narrative reflective practice is grounded theoretically in views of knowledge as personal practical knowledge ${ }^{11}$ and as narrative knowledge, as individuals live out, tell, retell, and relive their stories. ${ }^{12-14}$

Acknowledging the contextual and fluid nature of identities highlights the relational and the 'always in the making' aspects of identities. Whether one adopts a Bordieuian ${ }^{15}$ notion of habitus (acquired patterns of thought and behaviour) or a more narrative notion of identity, there is agreement that identities are both lived and told. ${ }^{12}$ In both
Correspondence: Jean Clandinin

Room 633, Education South, University of Alberta, Edmonton, Alberta T6G 2G5 Canada

Tel +I 7804927770

Fax +I 7804920113

Email jean.clandinin@ualberta.ca 
narrative and Bordieuian notions of identity, identities are both individual and social. As Monrouxe ${ }^{1}$ noted:

Performative aspects of identity are also present in the stories we tell to others (and ourselves): as we try to make sense of events our identities emerge as we story our individual experiences, positioning ourselves to cultural and social expectations ( $\mathrm{p} 44)$.

Attending to both lived and told stories of who we are, and are becoming, as professionals, highlights the importance of attending to the relational aspects; that is, to people, places, and events in interaction. ${ }^{16}$ The relational aspects of the living and telling of our stories always shape our stories to live by; who we are. Further, our stories to live by are always nested within, and shaped by, familial, institutional, cultural, social, and linguistic narratives. ${ }^{5}$

\section{A pedagogical approach}

Within narrative reflective practice, one pedagogical strategy involves working with physician learners to have them write, share, and collaboratively inquire into what Charon ${ }^{17}$ calls parallel charts of their experiences. Charon, as we do, works from a narrative view of experience in which people both live and tell stories of their lives. She asks medical students to write stories of their experiences with patients in parallel charts. In parallel charts, students write those things that are critical to the care of their patient that do not belong in the hospital chart but have to be written somewhere.

In current work, we further developed the pedagogical strategy by engaging family medicine and internal medicine residents in writing parallel charts and subsequently engaging them in small-group shared inquiry into the charts. This process of narrative reflective practice allowed each resident to tell his/her story in a parallel chart, which then became the starting point for the group's shared narrative inquiry. ${ }^{12}$ The group, with the guidance and support of a physician and a narrative researcher, narratively inquired into the story by asking questions that point toward temporality (the past, present, and future), the personal (what was happening for the person), the social (what events were unfolding), and place. Engaging in this way also directed attention to the multiplicity of vantage points one can adopt within the story, to the characters, and to the gaps, silences, and tensions within the stories. Unpacking the stories using this approach enhances the learning for both the resident sharing the story and his/her peers within the group. While the learning may have many foci, such as, for example, clinical knowledge, skill-based knowledge, or attitudes, the learning shapes the professional formation of the physician identity.

\section{Research methods}

Ethics approval was obtained from the Faculty of Medicine and Dentistry Health Research Ethics Board. Informed consent from all participants was received. Pseudonyms were used for participating residents. Volunteer residents were recruited from the Family Medicine and Internal Medicine residency programs. Participants were asked to write 10 parallel charts on clinical encounters over a 10 -week period and to attend biweekly sessions to read and inquire into their parallel charts with other participating residents and two researchers, one physician and one narrative researcher. In total, there were two groups from Family Medicine (eight residents in total) and one group from Internal Medicine (three in total).

After five sessions, individual, short exit interviews on what each resident had learned from their experiences were held. We previously presented the results of those interviews. ${ }^{18}$ Here, we draw on the transcript data from five collaborative narrative inquiry sessions with a particular focus on one resident's experience to show the ways this pedagogical strategy attends to the development of physician identity. In other places, ${ }^{10}$ we describe the collaborative inquiry process we use as a pedagogical strategy.

There are limitations to this study. The residents, including Leslie, were all volunteers. We have only worked with residents from two specialties, family medicine and internal medicine.

\section{The participants}

Leslie was one of three residents who participated in the internal medicine inquiry group, alongside Andrew Cave, a family physician, and Jean Clandinin, an educational researcher. The group met in a room in the hospital on five occasions late in the afternoon. A light supper was provided. The residents were volunteers, and while they were in the same residency program, they did not know each other well at the outset of the group meetings. Neither researcher knew them prior to beginning.

For each session, the group gathered around the table, and the residents took turns reading their parallel charts. After each reading, they engaged in a shared inquiry into the experience storied in the chart. Andrew and Jean frequently opened the inquiry conversation.

Our intent in this paper is to show how this approach provided an opportunity for Leslie to attend to how she was composing 
her physician identity by narratively inquiring into the stories she wrote in her 10 parallel charts and through her participation in the shared narrative inquiry in the five sessions.

\section{Leslie's experience as an illustration of narrative reflective practice as identity work}

Leslie volunteered to read her parallel chart first in the first session on December 17, 2007. In that chart she read of her first day in the cardiothoracic unit with a patient, Mr. H. It was an experience that made her feel "awful". Even though she knew "he was a very sick man", she "felt responsible for his sudden decline even though my colleagues assured me I had been a good doctor ... I kept wondering if I'd missed something, if I should have done something differently that could have changed his course". This wonder about being "a good doctor" focused the group's attention almost immediately on questions of her stories to live by, her developing identity, as a physician.

Leslie often wondered if she had been a good doctor during the inquiry groups over the following 10 weeks. For example, in the January 8, 2008 session, Leslie again wondered if one of her practices made her "a bad doctor". She drew attention to her living stories as well as to how she told her stories.

Her identity wonderings about being a "good doctor" appeared threaded together with wondering about whether others saw her (ie, storied her) as a doctor. For example, in that first session (December 17, 2007) when she questioned whether she was a "good doctor", she also spoke of feeling uncertain about introducing herself as Dr Bradley. She described how she was often seen or storied as "a nurse" even though she named herself as a physician. Three weeks later in the January 8, 2008 session, she also spoke of being called a nurse by a patient even though she told the patient repeatedly she was a doctor. Later in that session she spoke of how some patients' lack of respect around acknowledging her as a physician could "definitely put you off for that night". This wonder about whether she lived her practices from within a story of physician and whether others storied her as a physician recurred. In the February 7, 2008 session, Leslie reminded Elaine, another participant, of an earlier conversation about breaking bad news to a patient. They had both spoken of "not really being confident and I still don't know, even though I'm a resident, if that's really my job. What if I was wrong and scared her or something? So I've been trying to take a more active role in informing patients of bad news". In this quotation, she wonders about the parameters of her work as a physician but she also questions whether she can be a "good" doctor, one who does not make mistakes or scare patients.

Her concerns about whether she was a "good doctor" also reappeared in the February 7, 2008 session as she read another parallel chart. She wrote:

feeling sick to my stomach' cause at that point I was thinking 'oh my god, what did I do?' I didn't come to see this guy when he vomited, like I might have caused him to be like this ... And this is all my fault was all I could think ..... so I felt, I guess the worst part of it was just standing there at the end of the bed watching him and thinking 'oh my god, did I do this?'.

Later in the session she added that "in the end now knowing the results, it would not have made a difference". As she inquired into who she is becoming on February 7 , she told herself and the group "you can't blame yourself for everything. I mean it's what we do because we think we're supposed to fix everyone but sometimes bad outcomes just happen". In the session, Leslie returned again and again to her experience, finally noting:

I feel better now knowing what the cause was. And I think to myself, like I don't know. If you guys got that call, would you go? Or if you were busy, would you just think, 'It's okay, he might have aspirated but 97\% sats, he's fine'. Like I guess that's kind of the whole .... like it makes you feel better if people agree with .... your judgment.

In the first four sessions, Leslie often opened up questions about what being a good doctor was for her and frequently checked with the other participants about how they would have acted in the situations she storied in her parallel charts. Who she was and was becoming as a physician was a central focus in her charts.

The fifth session was almost 6 weeks later, on March 20, 2008. Due to scheduling difficulties, the group was unable to meet earlier because Leslie was in Trinidad. In this last session Leslie shifted temporally in her parallel chart writing, beginning with revisiting her first chart and the beginning of her residency and ending with a recent experience. She read her chart somewhat reluctantly, knowing it was the final chart (Table 1) to be read in our group.

As she finished reading, the group began the inquiry. By now, our group had a rhythm for the shared inquiry. Andrew acknowledged her with a gentle "mmm" and Jean clarified the temporal span, from the "start of residency" to Leslie's comment that the second part of the story was from "just last 
Table I Leslie's final parallel chart - March 20, 2008

First time I was ever on call as a resident the shit hit the fan. I looked calm on the outside but my heart was racing and I was full of doubt about what to do. I had learned the theory about what to do in case of various emergencies but l'd never been, never before had been the one to be relied upon. After a while I got accustomed to being on call and dealing with ward issues. That was until I started Cardiology and I had to carry the code pager. From the minute my first Cardiology call started, my stomach was in my throat. Every time the overhead speaker buzzed on, I crossed my fingers it wasn't a MET call or a code blue. My first night on call my colleague handed me the code pager at 4:50 and at 4:57 it went off. I stared at it in disbelief. It means that I was holding that stupid thing and it went off and I was off and running. I arrived at the code at the same time as the monitor. They asked who was running it and I said I was. Thankfully my senior was still in house and so was in the room. The nurses attached the monitor and I went through the initial steps of ACLS protocol ... oxygen and asking what had happened. And then my senior kind of nudged me and suggested I might want to look at the monitor. I was flushed and my pulse was probably about 120 and the sweat was rolling down my forehead. I was so rattled by the fear of trying to run a code that I had totally forgotten to even look at the monitor. The monitor showed a heart rate of 35 . The first thing I thought was "Oh my god. What am I going to do now?" And then I ordered the appropriate medications. However it didn't take very long for a pushy nurse to actually physically push me out of the way, totally minimizing me and adding to my anxiety. And I let her push me out of the way. I felt insignificant and incompetent.

So fast forward 6 months, I'm now at another hospital where there are no seniors in house and only your staff is your backup. I get called about a man having severe chest pain and a low blood pressure. I tell them I'll be right there to assess him. I walk quickly but I don't run. I'm not thinking about what I will do for this guy. I'm thinking about how I was hoping to have a short break on this really busy call, and how I was eating dinner and watching something on 60 Minutes about sleep deprivation and the bad things it does to a person's body, and how l've already worked 18 hours and will still be working for at least another 10.

In any event I arrive in his room and very calmly ask the nurse to get a bunch of tests going. He's $97 \%$ sats so this kind of ruled out one of the things I was thinking for causing his pain. I questioned him about his pain, asked him the details very calmly, ordered a bunch of things like aspirin and a Pink Lady. I glanced at the portable vitals machine and notice his heart rate is 30. "Interesting", I think. "What's up with that?" I wonder. So I ask, I hear myself say, "Can you get some atropine please?" If I took my own pulse now it would probably still be in the 60s just as it normally is. And, as I'm waiting for the atropine, his heart rate jumps to 100. I get the ECG during this time. He's bradycardic and then I leave to read it. I can't read it. It's the craziest ECG I've ever seen. I decide to go down to the ER to see if one of the ER doctors can help me read it so I can then call the staff to tell her that her patient dropped his pressure. Before I leave I check on the patient and his chest pain's gone. I have no idea what made it go away, if it was the Pink Lady or time or coincidence. One of the ER physicians doesn't mind looking at the ECG with me but it's so abnormal he really doesn't have a good diagnosis either. And neither do my other colleagues. "Oh well", I think "I guess l'll call the staff without an ECG diagnosis". A little while later he drops his pressure again so I go to see him and he feels fine. I check his heart rate and one minute it's 90 and the next minute it's in the 20 s. He ends up in CCU that night and is going to need a pacemaker. He doesn't code before being transferred as I anticipate he will.

When I'm finally finished admitting patients and I have a second to think I marvel at the calmness l've achieved in my last 6 months of residency. I can now deal with a pre-code without adrenaline coursing through my body causing me to sweat and have palpitations. The answers just automatically come to me about what to do. I trust myself more. I listen less to the criticism of the nurses or the RTs when they don't think what l'm doing is right. I still have doubts but, if nothing else, residency has given me a gentle calm in place of profound stress. I might have the worst karma among my colleagues. No one else had four codes in one night on Cardiology and yet that was fairly normal for all of my calls, in fact some people never even had a single code during their rotation. But with each day that passes, and with each time my pager goes off, I find myself more and more equipped to deal with issues that are at the other end of the phone. Residency has taken a lot away from me including sleep and free time but the confidence and calm it has instilled in me has proven to be a good thing.

Abbreviations: ACLS, advanced cardiac life support; CCU, Cardiac Care Unit; ECG, electrocardiogram; ER, emergency room; MET, medical emergency team.

week, this week". When asked about how the writing made her feel, she said:

Pretty good I guess. Because I remember standing in that room thinking, 'I'm going to faint', or something during the first code I was at. My god how stupid. I forgot to look at the monitor, I don't remember the dose, I was just sweating, like sweat pouring. And then during the second code, I didn't even, like I was just, it just popped out, 'Oh can you give me some atropine please?' Like my heart wasn't going fast it was just, whatever, like he'll be fine and it ended up I didn't need that anyway.

Andrew wondered if she thought the change she noted in herself was "a good thing or bad thing" and Leslie noted:

I wouldn't say it's complacent. But was it a good thing? I think it's not like, it's definitely not a complacency, it's just more of a comfort that, more confidence that I can handle some stuff. And it's all really just experience. I mean first you learn about it in books and then you see it with other people as a student and then when you really have to do it on your own, that's when you really learn.

At this point in the session and later as we reread the transcript of the chart and the inquiry into the chart, it was evident that Leslie had begun to live and tell herself a story of herself as a physician. In Leslie's story of the first code, she showed she was not telling a story of herself as a physician: she was unsure, nervous, easily rattled, and forgetful of correct procedure. She allowed a nurse to "actually push me out of the way, totally minimizing me". Six months later, she told of herself as "very calmly" asking questions and ordering tests and medications. She described herself as confident and calm. 
In the chart she read, it is clear that she now lives and tells a story of herself as a physician. However, as the shared inquiry into Leslie's final chart continued, Jean turned the conversation to the timing of Leslie's decision to write about the changes she saw in herself. Leslie noted that she decided to write it just a day or two earlier when she needed to write something for her parallel chart. And it was here that Leslie, and the rest of the group, learned more about the potential of narrative reflective practice for attending to physician identity. The space created by joining the research project (ie, by agreeing to write the parallel charts of her experience and to collaboratively inquire into them in the group meetings) allowed Leslie to attend to (to notice) the changes in who she was and was becoming over time.

Leslie explained her decision to write these two side by side stories of her experiences, one from the outset of her residency experience and one from the past week. She explained:

Well actually the funny thing is whenever I get on a plane ... I fear they're going to call for a doctor every time and I've flown like in the last year maybe 10 or 12 times. And so while I sat [on planes I'm thinking] 'my god I hope they don't call for a doctor'. I was on my way home from Trinidad by myself [last week]. And flying from Minneapolis to Edmonton, and suddenly I, it was actually quite embarrassing because I was reading Marley and Me, which is a very good book and they'd just put the dog to sleep. So I'm like crying and trying to hide my tears ... I had tear stains on my face and they're like, 'if there's a doctor on board could you please come to the back of the plane'. And I think 'oh, now it starts'. So anyway it ended up being just like kind of managing one of the ward things and I thought, 'wow that really wasn't as bad as I thought it would be'. Like I was actually very calm. ... And the thing that kind of surprised me because I'm a very, quite a passive person. And so when people push me out the way or whatever I usually kind of just let them so I've had to learn not to do that. And [another] lady that had been sitting on the plane came up and kind of pushed me out of the way and was like asking [the woman] these questions. And I said, because I was trying to get her to drink some orange juice and to eat some candy and she's like 'no she's going to choke on it blah, blah'. I'm like, 'well I'm a doctor. Are you a medical professional? And she's like 'no'. And I said, 'well you know I'm worried that her sugar is low, she hasn't eaten all day'. And she's like 'Oh, OK. Well then you must know what you're doing. And it was actually kind of a big step for me because normally I don't tell people I'm a doctor (Transcript, March 20, 2008).
As the group continued to inquire, Leslie added, "Anyway so that experience kind of made me realize how much I've learned, I guess, since the first day of residency". When Jean noted "what a different story you're telling about yourself and who you are", Leslie cautioned "well in that moment". In this Leslie acknowledged that identities are always in the making, dependent upon particular times and particular social and institutional narratives.

Again in reading the transcripts of the shared inquiry, Leslie helped us learn more about the narrative reflective practice process in attending to physician identity. In the shared inquiry process, Leslie moved beyond what she had written in the final chart to show that she was now living and telling a story of herself as a physician even when she was out of the hospital context. Stripped of her doctor clothing and in the midst of a personal context (on vacation, reading, on a plane) she was able to now confidently live a story of herself as a physician. She was even able to name herself as a physician and assume control in the face of being contested.

Jean, trying to find out if it was the parallel chart inquiry process that influenced Leslie, asked, "But I'm curious about these stories. If you write them for here, is this the moment that you stop and, and actually try and gather your thoughts together around this?" Leslie responded, "Usually, I think. Yeah, yeah".

The other members of the group also responded to this question and Elaine said, "I don't think I've told many of the stories or any of them to anyone else". Leslie noted she told one of her humorous stories "many times". Jerry noted he told some of his stories to other people but that:

Other ones are just things that stick and then when you put words to them because we don't do this often right? ... This type of thing where you sort of like pick a case and think about it in a different way. You don't have to write down all the stuff that we have to write in the charts. So ... when we have a meeting booked and it's coming up, you sit down and you sort of fan through your Rolodex and you say, all right what am I going to tell Jean and Andrew about this week?

As the conversation continued, the three residents considered how they wrote about different experiences for the group than the stories they told in other settings. Leslie said she tended "to talk more about the funny things like for entertainment purposes as opposed to like [what we do] here". Elaine said "yeah" agreeing with Leslie's unfinished sentence. Leslie added, "We deal with enough, I guess, sadness and whatever, so everyone, like all of your colleagues experience 
those things but the funny stories are the ones that stand out and I think you're, there's a little bit of a different dynamic I guess or expectation, whatever". In this exchange, Leslie also shows us the shaping influences of particular institutional and social narratives. In many spaces, perhaps, physicians in training learn to fit into institutional plotlines in order to not be seen as socially and emotionally vulnerable.

\section{Narrative reflective practice as a pedagogical strategy in identity making}

One way of thinking about the writing of parallel charts as identity making work is to see it as a work in hindsight. As Freeman ${ }^{8}$ wrote:

The narrated life is the examined life, where one steps out from the flow of things and seeks to become more conscious of one's existence. Along these lines, autobiographical narratives are not only about what happened when, how these happenings might be emplotted, and so forth, but also about how to live, and whether the life is a good one.... On the one hand, there is reference to recounting and understanding. But there is also a reference to "gathering together", to remembering what is most significant and worthwhile in a sometimes forgetful life (pp 176-177).

Freeman's words help us explain what Leslie allowed us to see in the writing and reading of her final parallel chart. She was gathering together, remembering what was most significant and worthwhile in her residency experience. In the shared inquiry, Leslie drew upon experiences from outside her professional training that are also constitutive of her professional identity. She drew forward experiences, from other places and times, to show that becoming a physician depended upon more than her hospital experiences. We saw her, in both the writing and the inquiry into the parallel charts, as engaged in an exercise in what Freeman called mindfulness, "a kind of respectful attention to the 'separateness and differentness' of one's own self, even a capacity to behold 'oneself as another' as Paul Ricoeur has put it" (p 229).

What Leslie showed us illustrates the power of the narrative reflective practice process and the use of parallel charts as a pedagogical strategy for the development of professional identity. She showed us that her professional identity is shaped over time, over multiple landscapes, and is always in the making. As Hoffman ${ }^{19}$ noted, "we do not only define ourselves; we are also defined by our circumstances, culture, the perceptions of others and - perhaps most of all - the force of an internalized past" (p 27). Leslie also showed through the inquiry process that who she is as a physician is embodied. She drew attention to her bodily responses as she allowed herself to be pushed or not, as her heart rate increased or slowed, and as she felt her body be calm.

Looking back, engaging in what Freeman ${ }^{12}$ calls hindsight, is "a vehicle of narrative reflection, binding together the disparate episodes of our lives into story" (p 8). By engaging in writing parallel charts and in the shared narrative inquiry into the stories lived and told also enables physicians in the making to shift those stories, to retell and relive who they are and are becoming as physicians in the making. As they compose their backward looking stories, they also begin to compose forward looking stories for themselves, stories of who they are becoming as physicians. Given the recent calls for medical education to become more attentive to the development of physician identity, ${ }^{1}$ we see this pedagogical strategy as one promising approach.

\section{Acknowledgments}

The authors gratefully acknowledge and thank participating residents and the support of the McLeod Fund in the Department of Family Medicine, University of Alberta, Canada.

\section{Disclosure}

The authors report no conflicts of interest in this work.

\section{References}

1. Monrouxe L. Identity, identification and medical education: why should we care? Med Educ. 2010;44:40-49.

2. Gee J. Identity as an analytic lens for research in education. Rev Res Educ. 2001;25:99-125.

3. McAdams D. The Stories We Live By. New York, NY: Guilford Press; 1993.

4. Connelly FM, Clandinin DJ. Shaping a Professional Identity: Stories of Educational Practice. New York, NY: Teachers College Press; 1999.

5. Clandinin DJ, Huber J, Huber M, et al. Composing Diverse Identities: Narrative Inquiries into the Interwoven Lives of Children and Teachers. London, UK: Routledge; 2006.

6. Greene M. Releasing the Imagination. San Francisco, CA: Jossey Bass; 1995.

7. Johnson M. The Body in the Mind: The Bodily Basis of Meaning, Imagination and Reason. Chicago, IL: University of Chicago Press; 1987.

8. Freeman M. Hindsight: The Promise and Peril of Looking Back. New York, NY: Oxford University Press; 2010.

9. Taylor C. Sources of the Self: The Making of the Modern Identity. Cambridge, MA: Harvard University Press; 1989.

10. Clandinin DJ, Cave M. Creating pedagogical spaces for developing doctor professional identity. Med Educ. 2008;42(8):765-770.

11. Connelly FM, Clandinin DJ. Teachers as Curriculum Planners: Narratives of Experience. New York, NY: Teachers College Press; 1988. 
12. Clandinin DJ, Connelly FM. Narrative Inquiry: Experience and Story in Qualitative Research. San Francisco, CA: Jossey-Bass; 2000.

13. Mattingly C. Acted narratives: from storytelling to emergent dramas. In: Clandinin DJ, editor. Handbook of Narrative Inquiry: Mapping a Methodology. Thousand Oaks, CA: Sage; 2007.

14. Schafer R. Retelling a Life: Narrative and Dialogue in Psychoanalysis. New York, NY: Basic Books; 1992.

15. Bourdieu P, Passerson JC. In: Nice R, trans. Reproduction in Education, Society and Culture. Thousand Oaks, CA: Sage; 1977.

16. Clandinin DJ, Connelly FM. Teachers' Professional Knowledge Landscapes. New York, NY: Teachers College Press; 1995.
17. US. National Library of Medicine. Dr. Rita Charon (video transcript). Bethesda, MD: US. National Library of Medicine [updated 2010 Oct 18]. Available from http://www.nlm.nih.gov/changingthefaceofmedicine/ video/58_1_trans.html. Accessed Sep 292010.

18. Clandinin DJ, Cave MT, Cave A, Thomson A, Bach H. Learning narratively: cross-discipline residents' experiences of a parallel chart process. Internet J Med Educ. 2010;1(1).

19. Hoffman E. After Such Knowledge: Memory, History, and the Legacy of the Holocaust. New York, NY: Public Affairs; 2004.

Advances in Medical Education and Practice

\section{Publish your work in this journal}

Advances in Medical Education and Practice is an international, peerreviewed, open access journal that aims to present and publish research on Medical Education covering medical, dental, nursing and allied healthcare professional education. The journal covers undergraduate education, postgraduate training and continuing medical education including emerging trends and innovative models linking education, research, and healthcare services. The manuscript management system is completely online and includes a very quick and fair peer-review system. Visit http://www.dovepress.com/testimonials.php to read real quotes from published authors.

Submit your manuscript here: http://www.dovepress.com/advances-in-medical-education-and-practice-journal 